\title{
Characteristics of Women's Consumers Behavior and Strategies of Enterprises Marketing Based on the New Media
}

\author{
Daowen Ren* \\ School of Management \\ Guangdong Polytechnic Normal University \\ Guangzhou, China \\ 1507485896@qq.com
}

Xuejun Liu

Marketing Department

Globaltimes International Consulting Corporation

Ontario, Canada

\author{
Haiyan $\mathrm{Wu}$ \\ South China Business College \\ Guangdong University of Foreign Studies \\ Guangzhou, China
}

\author{
Jiaying LV \\ Management \&Organization Studies \\ Western University \\ Ontario, Canada
}

\begin{abstract}
The new media is changing the traditional mode of communication, meanwhile, is yet transferring the behavior of women's consumption. In this respect of users' consumption, women's now occupy a large advantage. Women's consumer demand and behavior don't only represent the new spirits of the new media age, but also promote the prosperity of the new media. Based on the theories of communication, consumption behavior and marketing, using the method of literature research, this paper analyzes characteristics of women's consumer behavior under the situation of the new media, puts forward the corresponding strategies of enterprises marketing. The research results provide theoretical basis for enterprises marketing, and strong guidance for women's consumption in our country.
\end{abstract}

Keywords-New media; Women's consumer behavior; Features; Enterprises marketing

\section{INTRODUCTION}

The spread of the new media has not only brought the great changes in the field of communication, but also offers the great impact in the area of the politics, economy, society, culture and commerce, especially in the field of the marketing business. Many organizations and enterprises have begun to pay attention to the new media and apply the new media in the brand promotion, dissemination of information and services as well as the product marketing, and have achieved good marketing communication effect. Up to Dec.2014, the size of netizen in China were 649 million. The mobile phone is the net terminal that the netizen often uses. Using the rate of a mobile phone is $64.1 \%$. The rate of netizen of male and female is $50 \%$ for recent years respectively (CNNIC,2015)[1].So research of the new media and women's consumer behavior began to attract scholars' attention, has become a new research topic.

\section{FUNDAMENTAL THEORY}

\section{A. New Media}

Modern science and technology such as the cloud computing, intelligent mobile phone terminal and mobile internet have provided various kinds of information services. Information communication has changed the traditional mode of economic life style and also affected the way of providing social public information and social relationship management mode (Gao Gang, 2011)[2]. Such as the micro-blog has become a diversified public opinion place. Micro-blog's popularity has not only changed the path of existing public opinion, but also changed reality of social discourse power (Chen Lidan, 2011)[3]. Since human beings enter the new century, the social level of the new media has been gradually improved. Nature of the new media has changed. It can be said that the new media to a large extent has been equivalent to the actual sense of the social media. The current new media has played an important role in a country's economic development and industrial upgrading (Ying Yungong and Liu Ruisheng, 2011)[4]. The new media, also called digital media or net media, is the media total to be built based on computer information processing technology and internet to develop its communication function (Chengyu Xiong, 2012)[5]. The new media is a carrier of information communication that uses digital equipment of computer and so on (Wenbo Kuang, 2012)[6]. The new media has characteristics of strong interactivity, personal, nonlinear, multimedia communication, digital technology and so on. The author think the new media is based on the digital technology, relied on the Internet, the realtime communication, and has a strong interactive and the social characteristics. On the basis of scholars' research, this paper defines the new media as the spread of a new social media by the micro-blog, blog, forum, WeChat and social network. 


\section{B. Behavioral Consumption Theory}

Consumer behavior is a kind of decision-making process that the consumers take a variety of behavior and the behavior decision-making for obtaining, using, disposing of the consumer goods and services (Nicosia F. M., 1968)[7]. Martin Fishbein and Icek Ajzen first proposed the theory of rational behavior in 1975 (Theory of Reasoned Action, TRA)[8]. Attitude, intention and behavior are three main parts of TRA, and intention is core element of TRA. In 1980, Martin Fishbein and Icek Ajzen enriched TRA and thought: individual behavior intention determines individual behavior, the stronger person's behavior intention is, the higher the possibility of doing some behavior is. Technology Acceptance Model (TAM) is put forward by Davis (1989) on the basis of TRA[9].TAM proposed two key elements: 1)Perceived usefulness, it refers to the degree of efficiency when an individual use a specific system; 2)Perceived easiness of use, it refers to the individual's awareness of whether the system is easy to operate. The theory of planned behavior (TPB) is proposed by Ajzen (1991) on the basis of TRA[10]. TPB increases perceived behavioral control, and contains intention to the model to better predict the behavior. Torben (2002) used TRA and TPB at the same time when studying the field of online retail consumer's purchase behavior. He found that the explanation of TPB about online consumption intention was significantly stronger than TRA[11] Furthermore, Yang \& Zhou (2011) used the "perceived usefulness" and "perceived easiness of use" of TAM, and found that the TRA has strong explanatory power on consumer attitude, intention and behavior after the theory fusion[12].Ying Sijiu (2008) thought the factors affecting the consumers behavior mainly include the social, cultural, economic, family and other external factors as well as motivation, needs, attitudes, personality and other psychological factors; Consumers' purchasing decisions are the result of combining these factors, and many factors cannot be changed by the marketing personnel, but they are very useful for identifying the potential target groups of a certain product[13]. The marketers can influence these factors, which can help them to develop the marketing strategies in order to stimulate the consumer's response. Hawkin and Mothershaugh (2010) suggested that all market decisions should be based on understanding consumer behavior[14].Behavioral consumption theory is based on analysis of consumer behavior, and integration of the mainstream consumer theory, will become one of the future direction of macro consumption theory. Behavioral consumption theory provides a theoretical basis for studying of women's consumer behavior.

\section{Marketing Theory}

The factors of enterprises' marketing include internal factors and external factors that are concluded four points: Product, Price, Place, Promotion, namely 4P marketing theory. In the 1990s, Lauteborn, an American marketing specialist put forward 4C marketing theory. He thought that four factors of Customer, Cost, Convenience and Communication are the keys of marketing. The theory realizes enough that the consumers' need has a decisive impact to enterprises' success. At the same time, the enterprises should try their best to decrease the cost, to provide convenience for the customers, to pay attention to communicating with the customers.4R theory is combination of
4P and 4C theories. 4R theory are Relevance, Reaction, Relationship and Reward. It emphasizes much more relationship marketing, pay much more attention to long-term cooperative relationship between enterprises and customers. 4R theory has stronger validity and availability than $4 \mathrm{P}$ theory and $4 \mathrm{C}$ theory.

\section{CHARACTERISTICS OF WOMEN'S CONSUMPTION BEHAVIOR}

\section{A. Vividness of the New Media Communication Evokes Women's Strong Consuming Desire}

Steuer (1992) believes that vividness is the way that the media environment presents information to the sense organ[15]. The experimental results of Sewak et al. (2005) show that, in the case of the same information content, high vividness brings stronger visual attraction and more pleasure, which makes consumers have a more positive attitude. The new media communication use text, symbols, and colors, with background music, pictures, animation and other elements to raise its vividness and enhance the aesthetic features. The vivid and aesthetic communication form a strong impact on women's senses, so that stimulates the women's consumer desire of consumption. Meanwhile these provide a pleasant environment for product information. Also the positive external environment will have a positive impact on women's consumption. In addition, the majority of women who use the internet are middle school students, college students, general staff, private owners, freedom of occupation or company managers, who tend to browse as ones pleasures. When they often browse in casual, they produce the desire to buy many goods no needs. Therefore, they will buy the goods outside the plan imperceptibly. This situation has more than half proportion during women consumption, which shows that women's strong desire of consumption stems from senses of vividness of new media communication.

\section{B. Interaction on the New Media Communication Produces the Women's Consumption Behavior}

Ariely (2000) research got the result: During the process of information acquisition, consumers need to get more information, which interactivity can meet the needs of dynamic information [16]. The research of Sicilia (2005) concluded that, in the interactive website, consumers can have higher flow experience, resulting in a more positive attitude on products[17]. Through new media communication, interaction between women's and brand manifests in the aspects of information update, testing support, reviewing and getting privilege. The proportion of women's users above each part are greater than the proportion of the men. With the rise of mobile internet and social media, women can effectively use fragmented time, anytime and anywhere, to communicate with others to exchange and to share information. During this process of mutual communication, women are more susceptible to emotional infection and impact of the actual action to by exchanging and sharing information, so that stimulates women's consumer desire of consumption. Because women emotional factors often occupy dominant position during the process of consumption, and spread of new media just meets emotional needs of women's consumption. For example, when 
the best friends share successfully consumer experience, women's emotions will be infected. Although they tend to their own intuition and buying experience to decide, but they are also influenced by their friends' advice. When women frequently contact with the social media during shopping, when they accidentally see a picture, the information of a discount merchandise, or a consumer feedback, which share by the social circle of friends, they are likely to be affected by emotion of the moment to arouse the desire to buy.

\section{Perceived Usefulness of New Media Communication Make Women's Consumption Desire Strong}

According to TAM, the degree that women's customers perceive usefulness on new media communication has a direct impact on women's consumer intention. The more useful women's consumers perceive new media communication, the stronger desire that they use new media communication is. As results, they recognize much more the released value of the goods by new media communication. Gefen, Karahanna, \& Straub(2003) believed that Internet is a bridge between the consumers and enterprises[18]. During the process of transmission, Internet will pass actively the product into the hands of enterprise, and the more important transmission of information is if the product itself is useful. New media communication is a kind of special network products; visual information display is the key of women's consumer brand recognition and consumption intention. If new media communication can provide more useful information for women's consumers, then the consumers aware of the high possibility that enterprises meet demand. Similarly, the higher the possibility of brand identity is, the stronger the desire to consume is. The research of Vijayasarathy (2004) show that: perceived usefulness of consumers can be used to predict consumers attitude to online store, namely, there is a significant positive correlation between the two[19]. According to above analysis, the author think when women's consumers think dissemination of information can meet actual demand for shopping, that is, when women perceived that new media communication is useful, they will recognize value of the goods released, and will purchase these goods. Therefore, usefulness that women's consumers perceive new media communication is the basis of women's consumer purchase intention and purchase behavior, which is an essential factor about influencing women's consumer behavior.

\section{D.Participation by the New Media Communication Can Impact Women's Consuming Intention}

Schindler and Bickart (2001) found that comparing forum and company website, the forum can cause consumers to pay attention to the commodity to form a shopping interest than company website[20]. Because participation and exchange of a forum are more extensive, dissemination of information has not restrictions of time and space, can also protect consumer privacy well. Consumers can obtain goods evaluation and consumption information at any moment, which enhances consumers' perception of goods virtually.

Network community is the prototype of social media development. According to different characteristics and interests of users, network is divided into a variety of characteristics of community. The users of these different communities have the same label image. Through identifying women image, age, purchasing power, main characteristics and different identity in the social media, there shows a different distribution of the label style community. Through the common characteristics and shopping needs, the women with different labels gather together in the different network communities, performance on the social platforms. According to the different needs, the experts develop application software of mobile phone with the social nature. Taking "Hot Mom" as an example, the most of "Hot Mom" concern about parenting knowledge, cooking knowledge, and purchase of pregnant baby information in the Hot Mom's daily life, so they generally gather together in the kitchen, freaky help, baby tree and other mobile phone applications, and they instantly exchange and share the relevant commodity information with other Hot Mom who has the same needs. The mobile phone application software can meet the women shopping with "Hot Mom" label and living needs.

\section{E. "Celebrity Blogger" Had a Pursuit Impact on the Women's Consumer}

In the women's network community, the star effect brought by "Celebrity Blogger" regards as the soul of the community. "Celebrity Blogger" is good at clothing collocation and beauty skin, goods through online shopping, showing their own clothing collocation or beauty, good face by publishing photos and video. They have a lot of fans, and they move like a star by the fans hot pursuit. Through the social media, they share the goods that often become the fashion of Web site. For example, the fashion bloggers favorite "Choke Pepper", the number of Sina micro-blog fans are more than 6.24 million people, this is a very alarming figure. Due to public and openness of the social media, the users do not need the threshold, who can freely subscribe to browse. It can be said that their subscribers have greatly exceeded the number of the users of a fashion magazine. On the micro-blog and blog, they post the dress collocation that has been sought after by a large number of the fans. If searching online with "Choke Pepper" as the key words in Taobao, related products have exceeded 200 thousand, which has the huge business opportunity and which also shows the great influence of "Celebrity Blogger" on the women's consumers. Meanwhile it also provides a new idea of marketing for the brand and Online retailers.

\section{ENTERPRISES' MARKETING STRATEGIES}

According to analysis of the features above, the enterprises should take the following marketing strategies:

\section{A. Strategies of Applying 4P Theory}

The enterprises should design novel, beautiful and tasteful products to satisfy women's consumers' needs of the sense organ, to define connotation of products and to strengthen women's consumers' feeling guide according to the women's consumers' psychology; the enterprises should establish different prices according to various level women's consumers under the situation of new media; the enterprises should make use of new media to increase advertising, use various promotion ways, especially pay attention to using feeling to 
promote at site, many women act online shopping, group purchase, online pay and finance, online booking and so on as a part of their lives, some women make themselves into online shopping addiction. So the enterprises should perfect the sale service online, proper shorten logistic time, renew information in the time, simplify the process to improve convenience.

\section{B. Strategies of Using 4C Theory}

The enterprises should not only produce and provide corresponding products according to women's needs, but also want to perfect the various service online ; the enterprises may decrease sale price, save purchase time and offer high quantity service to satisfy the women's purchase psychology, namely, which they want to spend the lowest price to get the highest content and income ; the enterprises should obey the women's consumption psychology, the women's consumption behavior and the women's consumption habits, give them convenient and quick purchase pathway, and set up interactive marketing platform based on the internet, the enterprises also should communicate and interact with the women's consumers, go through experiential sale on the virtual transaction on the platform to decrease operation cost.

\section{Strategies of Utilizing 4R Theory}

The enterprises should establish the relationship of longterm, win-win and stable cooperation with the women's customers ; the enterprises should consider things from the women's perspective, and create the marketing pattern the situation of the new media targeting net community and the women's customers' need, such as the marketing strategy of search engine, word-of-mouth marketing as well as "web celebrity" and so on ; the enterprises must have long-term point of view, pay attention to long-term benefit rather than short-term benefit during the course that the enterprises make contact with the women's customers, the enterprises also should think about getting their income on the basis of satisfying with the women's customers' needs, because the income is starting points and the point of falling down from the horse that the enterprises' operate and the enterprises marketing.

\section{CONCLUSION}

A close review of new media illustrates that concept, under the situation of the new media, the women's consumption behavior is complicated and various, but we may find its regularity through the features of the women's consumption behavior. If the enterprises want to take up a place in the women's consumption market, they must understand the features of the women's consumption behavior under the situation of the new media.

\section{ACKNOWLEDGMENT}

This research was financially supported by the project of the normal university characteristic innovation of Guangdong province in 2017 and by the project of the Philosophy and Social Science in Guangzhou in 2018 (2018GXGJ73).

\section{REFERENCES}

[1] China Internet Network Information Center(CNNIC), "Statistical report on the development of the Internet in China" Beijing: China Internet Network Information Center, 2015.1

[2] G. Gao, "Network politics: from the form civilization to digital civilization," network communication, vol. 2011(2), pp. 36-38, 2011.

[3] L.D. Chen, "Mechanism on Micro-blog's self-discipline and self purification," network communication, vol. 2011(10).

[4] Y.G. Ying and R.S. Liu, The localization and socialization of new media in China, Beijing, Social Science Literature Press, 2011, pp. 1-12.s

[5] D.C.Y. Xiong, The research front of the new media, Tsing University Press, 2012.

[6] W.B. Kuang, "What is the new media exactly?" News and writing, vol. 2012(7).

[7] F. M. Nicosia, Consumer Decision Process, Marketing and Advertising Implication, Prentice Hall New Jersey, 1968.

[8] M. Fishbein and I. Ajzen, Belief, Attitude, Intention and Behavior :an Introduction to Theory and Research, Addison-Wesley Publishing Company, 1975.

[9] F.D. Davis, R.P. Bagozzi, and P.R. Warshaw, "User Acceptance of Computer Technology: A Comparison of Two Theoretical Models," Management Science, vol. 1989(35), pp. 982-1003.

[10] I. Ajzen, "The theory of planned behavior," Organizational Behavior and Human Decision Press, 1991, pp.179-211.

[11] Torben, "Predicting Online Grocery Buying Intentions: A Comparison of The Theory of Reasoned Action and The Theory of Planned Behavior," International Journal of Information, Management, vol. 2002(24), pp. 539-550.

[12] H. Yang and L. Zhou, "Extending TPB and TAM to Mobile Viral Marketing: An Exploratory Study On American Young Consumers' Mobile Viral Marketing Attitude, Intent and Behavior,' Journal of Targeting, Measurement \& Analysis for Marketing, vol. 19(2), pp. 8598, 2011.

[13] S.J. Ying, "The study of consumers' online shopping intention based on the theory of planned behavior," Consumption economy, vol. 2008(4).

[14] D.I. Hawkins and D.L. Mothersbaugh, Consumer behavior: building marketing strategy, Boston: McGraw-Hill Irwin, 2010

[15] J. Steuer, "Defining Virtual Reality: Dimensions determining telepresence," Journal of Communication, vol. 42 (4), pp. 64-73, 1992.

[16] D. Ariely, "Controlling the 1nformation flow: Effects on Consumers' Decision and making and preferences," Journal Of Consumer Research, vol. 27 (2), pp. 233-248, 2000 ..

[17] M. Sicilia and S. Kuiz, "Effects of Interactivity in a Web Site: the Moderating Effect of Need for Cognition," Journal of Advertising, vol. 34 (3), pp. 31-45, 2005.

[18] D. Gefen, E. Karahanna, and D.W. Straub, "Trust TAM in on-line shopping: an integrated model,” MIS Quarterly, vol. 27(1), pp. 51-90, 2003.

[19] L.R. Vijayasarathy, "Predicting Consumer Intentions To Use On-line Shopping: the case for An Augmented," Technology Acceptance Model, Information \&Management, vol. 41(6), pp. 747-762, 2004.

[20] B. Bickart and R. Schindler, "Internet Forums as Influential Sources of Consumer Information," Journal of Interactive Marketing, vol. 15 (3), pp. 31-52, 2001. 